\title{
The Historiography of Bleiburg and the Death Marches since Croatian Independence
}

\author{
MARTINA GRAHEK RAVANČIĆ \\ Croatian Institute of History
}

\begin{abstract}
Summary
This paper presents a review of recent research results and the published literature related to the topic of Bleiburg and Death Marches. The main accent is set on the data and knowledge about the (still) controversial events from the end of the Second World War and its aftermath in comparison with some currently (not) accepted knowledge.
\end{abstract}

Keywords: Bleiburg, Death Marches, 1945, Croatia, Victims

When we talk about Bleiburg and the Death Marches, ${ }^{1}$ we are covering a relatively "short" sequence of history, but its consequences are still felt, burdening and dividing Croatian society (and other societies from the former Yugoslavia) - to this day.

For introductory purposes, it is important to define the term about which we write. In case of Bleiburg and the Death Marches this is particularly important. Similarly, it is important to ask why after more than seventy years we still have to define what Bleiburg and the Death Marches exactly were and what they mean? It is because of the fact that many people still interpret these events very arbitrarily or in a biased manner. Consequently, it seems as if talking about the Bleiburg events we tend to justify or condemn certain ideologies, as we forget that behind these events are real human lives. These people and their lives, or at least some of them, were of little worth in 1945.

${ }^{1}$ In Croatia, these marches are referred to as Križni put. The literal translation would be "Way of the Cross" or "Stations of the Cross". This term is clearly connected with the passion of the Christ and reflects common popular attitude towards the problem of victims from the aftermath of the Second World War in the former Yugoslavia, particularly in Croatia. However, I believe that the term Death Marches is clearer to the international audience. Moreover, the international literature on the topic also uses this term. 
Therefore, the terms Bleiburg and the Death Marches include the fate of the people who were withdrawing from different areas of Croatia, Serbia, and BosniaHerzegovina towards the temporary position of the Western Allied troops (in the direction Celje - Slovenj Gradec - Dravograd - Bleiburg) at the end of the Second World War. In the refugees' column, there were members of various armies (units of the Third Reich, the Armed Forces of the Independent State of Croatia, ${ }^{2}$ Slovene Home Guard, and members of various Serbian and Montenegrin Četnik units), but also there were civilians who retreated to Austria due to fear of the Partisans and anti-communist propaganda. Many of them were captured by the Yugoslav Army (JA) in Slovenia before ever reaching the Austrian border. Some of the refugees, who had managed to avoid encirclement by the JA, arrived in Allied camps in Austria (Viktring, Krumpendorf, Töschling, Rosseg, Ferlach, Tamsweg, Grafenstein, Völkermarkt, and Wolfsberg). However, most of them were subsequently extradited to the Yugoslav Army. These extradited refugees, together with the troops and civilians captured by the JA, were all sent on a long return journey back into Yugoslavia, which resulted not only in imprisonment in numerous organized internment camps, but executions and burial in mass graves. For these reasons, the historiography and the wider public remember these events as the Death Marches.

The existing literature on the topic can be divided (conditionally) into three groups that correspond to the periods when the publications were written and issued. This classification reflects some general characteristics of the existing literature and consequently comprises its contribution to the clarification of the entire problem. The first significant step was taken in the émigré literature (Croatian, Serbian, and Slovenian), which openly spoke about the events from May 1945. Most of these titles can be classified as memoirs. From their contents, we can learn a lot, especially if one bears in mind that at that time (i.e. prior to the 1990s) it was forbidden to speak openly of this topic in socialist Yugoslavia. However, it should be noted that the texts are shaded with subjective impressions of people who endured these unfortunate events. Despite of this obvious lack of objectivity, even today there are many titles from émigré circles that are regularly consulted, analyzed, and quoted in studies about Bleiburg and the Death Marches. I do not agree with the general opinion that this type of literature is subjective and therefore useless. If we compare these titles with the literature written during the last twenty-five "objective" years, when there were many opportunities for establishing a new and more

2 By the end of 1944, the military leadership of the Independent State of Croatia (NDH - Nezavisna Država Hrvatska) merged the Ustaša units with those of the regular army, the Home Guards (Domobrani), into a single army, the Armed Forces of the Independent State of Croatia (OS NDH- Oružane snage $N D H$ ). 
empirical perspective, only then it becomes clear how such generalized criticisms have no real foundation and argumentation.

The next group consists of the literature that was written in the former Yugoslavia, in the period from 1945 to 1990. Most of the published titles, as can be expected, describe only "final operations for the liberation of Yugoslavia", and hence mention only the battles that occurred during the withdrawal of the fleeing NDH troops and refugee columns. Consequently, these authors ask no questions regarding the responsibility for what had happened, since the perspective they offer is solely from the winning side. According to them, the winners were entitled to the entire truth, and they were ultimately the only ones writing the post-war history. Therefore, it is reasonable to conclude that the official Yugoslav/Croatian historiography wrote a victory narrative according to the expectations. In spite of this, many of these publications are useful and should not be omitted, especially regarding the issues related to the negotiation process in the Bleiburg castle immediately prior to the capitulation of the NDH forces.

The democratization processes in the former Yugoslavia at the end of the twentieth century offered more freedom to write about Bleiburg, beginning in the 1990s. Consequently, at that time a great number of books were published. Most of them, however, were memoirs (autobiographical reflections) or books that were conveniently written for commemorating the Bleiburg anniversary. Similarly, many books about the commemorations have been published annually on the anniversary of the Bleiburg events. Thus, the topic of Bleiburg was included in encyclopedias, syntheses, textbooks for primary and secondary schools, and became a part of contemporary literature and even the film industry. Despite some initial genuine efforts to write a history of Bleiburg, there was no overall analysis of the topic. In the same period, especially in daily politics, we can notice the occurrence of many discussions, particularly regarding the number of casualties (i.e. victims), some of which remain debated even today. Therefore, a sense of discord is still present in Croatian society. Existing interpretations about Bleiburg differ considerably, as can be seen in the various works described below, while at the government level there is no real political will to solve the problem. Since certain political parties benefit from the annual polemics over the communist past and nostalgia for the defeated NDH, there is little interest to put the Bleiburg issue in the proper historical context so that it could finally become a part of the past and not contemporary politics. The path of acceptance and reconciliation is long and it takes time. Until then, every year, especially in May, Croatian society engages in the same debates over the Second World War while the media are dominated by commemorative spectacles and political speeches. The commonly offered and arbitrarily formed answers by each side often do match the desired "picture" of the past, and do little to advance scholarly 
research or a productive solution. Thus, the transition of consciousness is a long process that involves a lot of good will and acceptance of different interpretations.

If we start from the viewpoint of a general historical synthesis, which is primarily used to get acquainted with the overall events, we need to consider some of the available overviews of Yugoslav/Croatian history (written by foreign or domestic authors). The analysis of such literature provides useful insight into how the issue of Bleiburg was, and still is, heterogeneously perceived and interpreted (even in historiography). Among many authors, I would single out the book by Ludwig Steindorff, Povijest Hrvatske od srednjeg vijeka do danas (Croatian History from the Middle Ages to the Present), which describes in detail all of the important elements that marked the end of the Second World War. This includes the events at Bleiburg field and on the Death Marches, as well as the existing controversy about the estimations of the number of casualties. Another important aspect included in this study is the author's emphasis on the necessity regarding the unsealing of "critical discourse" about the issue. Because only such a discourse, after decades of silence, can resolve existing problems and trauma (Steindorff, 2006: 186-189).

Marie-Janine Čalić's synthesis Historija Jugoslavije u 20. veku (History of Yugoslavia in the $20^{\text {th }}$ Century) very accurately describes the Bleiburg events, emphasizing the key (controversial) moments, which include varied and unfounded numbers of casualties, places of extradition, etc. The author's conclusions are based on the relevant literature and in very few sentences she states what any book of this kind, in short, should bring. In the final conclusion, she correctly states that "since the communist state did not recognize or reveal the injustices committed in its name, the memory of the misdeeds committed at Bleiburg and at the foibe $e^{3}$ became historic political time bombs" (Čalić, 2013: 216).

In Dušan Bilandžić's monograph Hrvatska moderna povijest (Croatian Modern History) one can find a description of the end of the war, which the author refers to as "the political breakdown of Great Serbian forces" and "the breakdown of the Independent State of Croatia (NDH)". Bilandžić describes in quite a bit of detail the Ustaša and Četnik attempts to create an "anticommunist block" at the end of the war, the withdrawal of Army Group E from Greece through the Balkans, as well as the final operations of the Yugoslav Army. Moreover, the author clearly and extensively writes about unrealistic attempts of the government of the NDH to ensure the protection of the Allied forces at the very end of the war. However, the author offers only basic and brief information about the retreat of the NDH forces towards

${ }^{3}$ Foibe are the karst pits in Istria and the Slovenian littoral used to dispose the bodies of Italian fascists and suspected collaborators killed by the Partisans. As is the case with Bleiburg, there are numerous politicized debates about the number and nature of the victims. 
Austria, the negotiations in the Bleiburg castle, and the extradition of the captured troops on a single page. Similarly, events from the Death Marches are mentioned only through the overall estimation of the number of victims. Finally, Bilandžić presents Bleiburg and the Death Marches entirely through the prism of the futile final efforts of the NDH government, in particular their wrong assessments and unattainable expectations, for which the author's criticism is absolutely justified. However, in this synthesis the Geneva Convention is mentioned only in one short sentence, without questioning the possible liability of the JA forces for the subsequent liquidation of prisoners. However, as Bilandžić states, the NDH also joined and signed this convention, which means that it was binding for both parties, i.e. the NDH and JA forces. Bilandžić identifies the political and military leadership of the NDH as the sole culprits for the "tragedy". Still, in a single modest or almost imperceptible remark, Bilandžić also notes that "the culprits are the Allied military command that did not respect the Geneva Convention” (Bilandžić, 1999: 188). The responsibility of the JA is not mentioned at all. However, such an approach and analysis are quite expected because, in this monograph, there is no mention about what was happening with the prisoners on the Death Marches.

During the last few years Ivo Goldstein (sometimes writing with his father Slavko Goldstein) has published several historical syntheses, some of them as author and some as editor (Goldstein, 2003; 2008; 2011; Goldstein and Goldstein, 2011). All of these publications share a common basic text, whose length and content are expanded or shortened, depending on the purpose of the publication. The author(s) state that the transfer of such a text is absolutely adequate because it is " (...) for now the only one that concisely gives a comprehensive historiographical overview (...) review based on a precise study, unbiased historiographical approach, and without one-sided politicized interpretations" (Goldstein and Goldstein, 2011: 133). In these publications the topic of Bleiburg is often described as the Bleiburg "syndrome" or the "syndrome" of the Death Marches. According to the definition of the term, syndrome commonly refers to a group of symptoms that regularly occur together, but whose core cause or causes are partially or completely unknown. Such a concept assumes that there are quite a few uncertainties regarding the problem of Bleiburg and the Death Marches, and yet arguably the main aspects of these events have been researched and written about. The only remaining question is whether we can accept and acknowledge the existing explanations, or whether such answers and explanations are not supposed to be accepted. Namely, which parts are rather disputable? The most controversial aspects are related to the debates over numbers in the text, especially when the author states that "scrupulous" investigations show that the column of retreating troops consisted of between 100,000 and 150,000 people, "probably around 134,000" (Goldstein, 2003: 305). The first figures mentioned herein 
correspond with estimates in other sources, but it is unclear how the latter figure was calculated. Thus, one can only conclude that this statement is unfounded. Likewise, when talking about the number of casualties on the Bleiburg field, about which we do not have any reliable estimations, the author states without any hesitation that "twenty-seven Ustaše" were killed there (Goldstein, 2008: 363). By the same token, Goldstein mentions the overall assessment of casualties, referring solely to the works of Vladimir Žerjavić. This reference is not disputable, but it is indicative how the authors selectively use information because they state that according to Žerjavić's estimations there was a total number of 55,000 victims at Bleiburg and on the Death Marches, while in reality Žerjavić in his studies clearly has demonstrated that this figure of 55,000 victims refers only to Croats. Moreover, to this number Žerjavić adds Slovene losses, which are estimated to be around 8,000 to 10,000, together with about 2,000 Serbian and Montenegrin Četnik victims, which ultimately leads us to a figure of approximately 70,000 total casualties. This number is not stated in any of the above-mentioned syntheses written or edited by Goldstein. Similarly, although the authors recognize that the metaphor of the Death Marches is appropriate, they state that the degree of harshness depended "mostly (...) on the commander or the leader of the unit which escorted the prisoners. Spontaneous actions, retaliation, and robbery were frequent" (Goldstein and Goldstein, 2011: 156). They note that there were few questions about the responsibility for the liquidations and that there were no strict penalties for unsanctioned killings, yet the authors state that "there is a story that allegedly some Partisans were shot because of unethical conduct, but there are no documents to support this" (ibid.).

All things considered, it seems that foreign authors (with rare exceptions among domestic authors like Zdenko Radelić) are more precise in their conclusions and overall approach to the Bleiburg issue. This is especially noticeable when discussing the responsibility for committed crimes, while in the recent Croatian historiography this matter is mentioned only vaguely. The debates about Bleiburg in the public sphere and among politicians is even more superficial.

In the contemporary Croatian historiography the topic of Bleiburg was introduced by Darko Bekić in his article 'Slučaj Bleiburg': nova istraživanja, nova iskušenja (Case study Bleiburg: New Investigations, New Temptations). Bekić analyzed the so-called Cowgill Report. This report was intended to examine the responsibility of the British army in the events regarding the Bleiburg issue, and utterly to defend the reputation of the Royal forces. After a meticulous analysis, the author concludes that the results of the whole project remained "ambivalent", mostly because it holds responsible only persons at the bottom of the diplomatic and military hierarchy (Bekić, 1989: 214). The entire content is closely related to the question of negotiations held at the castle Thurn-Valsassina on a hill overlooking Bleiburg 
Field. Yet, the story and analysis about the negotiations are still based solely on what the negotiators of the three armies (British, Partisan, and NDH) left us in their memoirs. Each of them proposes his own view of the events, and they differ in all the key segments, sharing only some elements of the negotiation process (Jareb and Omrčanin, 1977-1978; Crljen, 1966; Basta, 1980).

Regarding the question of British responsibility for the handing over of prisoners, certain anomalies have already been noted by British historian Nikolai Tolstoy. Analyzing the question of the extradition of Cossacks and White Russians, he noticed a large resemblance to the fate of prisoners to whom the British sources refer as "anti-Yugoslavs". Consequently, Tolstoy's work raised many questions and discussions. Still, in his research Tolstoy is not judging everyone's responsibility according to the same criteria, and for some players (e.g. Field Marshal Harold Alexander) he finds comfortable excuses even though such excuses might not be entirely valid and easily justified. Nevertheless, Tolstoy's research made a great contribution to this topic. The British Ministry of Defense tried to refute Tolstoy's results by publishing relevant key papers and documents. Still, though the methodology of investigation was focused on primary sources (reports, telegrams, and war diaries) the final conclusions were influenced by higher political interests (Cowgill, Brimelow and Booker, 1990).

The most important contribution to historical research is the publishing of newly discovered documents. This importance increases especially if the documents that are published were previously unknown to a broader audience. These publications offer no (re)interpretation or revision of the presented historical events. Because of that, I must mention a series of books with published archival records titled Partizanska i komunistička represija i zločini u Hrvatskoj 1944. - 1946. Dokumenti (Partisan and Communist Repression and Crimes in Croatia 1944-1946: Documents). These four volumes represent a methodological pattern and novelty regarding the publication of this kind of documents in Croatia. A part of the published documents are related to the records from the operating diaries of specific units of the Yugoslav Army, which clearly witness events on the Death Marches and in prison camps along the way.

To avoid one-sided interpretations, one needs to mention titles and publications that describe the final operations of the Yugoslav Army in Croatia and Slovenia. Although a large part of them does not mention events on the Austrian-Yugoslav border, they are essential if we want to discuss in detail the retreat of refugee columns and the conflicts that followed in the broader region of Slovenia and Croatia. Thus, one cannot omit Franci Strle's book Veliki finale na Koroškem (The Great Finale in Carintia), published in 1977. This book presents a meticulous analysis of what was happening on a daily basis in May 1945 in the wider area of Slovenia. Therefore, 
this monograph is truly a valuable contribution to the study of the final operations in the territory of Yugoslavia.

In the beginning of the 1990s, many titles related to the topic of Bleiburg and the Death Marches were published. Most of them are memoirs written by people who survived the Death marches. Similarly, in this period scientific symposiums about Bleiburg were organized almost every year, and these conferences were followed by collections of proceedings. In these publications one can find numerous scientific and autobiographical contributions, as well as contributions which were specifically written for the occasion. Although many of these texts are subjective and colored by the conflicts in Yugoslavia, it is important to stress that some of them are a valuable contribution to the understanding of the Bleiburg events.

At the same time, many studies regarding the number of victims in the aftermath of the Second World War in Yugoslavia (Croatia) were also published. Realistic and valuable thoughts about the topic can be found in Jozo Tomasevich's book War and Revolution in Yugoslavia, 1941-1945: Occupation and Collaboration (2001), which was translated to Croatian in 2010. Regarding the question of the number of victims, so far the most comprehensive studies were written by the already mentioned researcher Vladimir Žerjavić (one of them is Opsesije i megalomanije oko Jasenovca i Bleiburga [Obsessions and Megalomanies about Jasenovac and Bleiburg]). His estimations are often disputed in the public, but many historians still accept his work as the most relevant. However, it should be noted that some of the latest historiographical investigations in Slovenia, Croatia, and Serbia suggest that these figures should be increased, but not as much as it is often mentioned in numerous émigré literature. Namely, the estimations of Žerjavić could be considered as the lowest reliable estimation in the assessment of the overall number of casualties at Bleiburg and on the Death Marches.

By the same token, valuable, but often partial, unverified, and incomplete data, which can be particularly important for local communities, can be found in numerous publications with lists of victims (žrtvoslovi). Many of such publications were published in the last twenty years. Based on the data presented in these books one can come up with some more accurate (though not complete) indicators regarding the number of victims at Bleiburg and on the Death Marches.

Regarding the question of the number of victims, as well as the investigation of mass graves, Slovenia (and partly Serbia) have done much more than Croatia. In an institutional sense, in 1991 the Croatian Parliament founded a Commission for resolving the question of war and post-war victims. It began functioning in 1994, but already by 2000 its work was stopped and in 2002 the Commission was definitely abolished. The most comprehensive list of victims that the Commission left us dates from 1999, and according to this list only 13,300 persons were killed at 
Bleiburg Field and on the Death Marches. It is not necessary to elaborate and stress that this number is far from the final conclusion based on the figures cited in communist sources as well as in subsequent estimates. Therefore, one has to admit that the Commission has not fulfilled its primary mission and its presented results have a minor significance in public life and in the historiography.

Consequently, we were left with high hopes and lots of good will that some future projects would give more accurate results. Unexpectedly, in 2011 the Croatian Government established the Office for discovering, marking and maintaining graves of victims of communist crimes after the Second World War. Shortly after that, this office lost its autonomy as a public institution and was renamed the Committee for research, arrangement and maintenance of military cemeteries, the cemeteries of the victims of the Second World War and the post-war period, subjected to the control of the Ministry of Veteran Affairs. However, one has to stress that the form of organization of this institution is less questionable and problematic than the results this committee has produced. Moreover, it is questionable who, and when, has consulted anyone among the institutions (or individuals) who dealt with these questions in Croatia up to the present day. In this case the most important concern of the founders was to organize the office, with little effort invested into the content, which should have been its primary task. Because of that the achieved results remain insignificant. Namely, during the last seven years this office conducted only few excavations in Zagreb surroundings, without any public outreach. Consequently, even those poor results remained unavailable for broader audience and researchers. And in that manner, such a sequence of unfinished and utterly vague projects was "successfully" continued, as it was the case with the Commission that was ceased in 2002.

On the other hand, it is important to note that only recently, lawyers have analyzed legal aspects of the crimes committed in Bleiburg and on the Death Marches. Among these studies, the article by Dominik Vuletić "Kaznenopravni i povijesni aspekti bleiburških zločina" ("Criminal law and historical aspects of the Bleiburg crimes"), published in the journal Pravnik (2007), stands out. The legal and normative framework of these events is also explained in Dieter Blumenwitz's book Okupacija in revolucija $v$ Sloveniji (1941-1946). Mednarodnopravna študija (Occupation and Revolution in Slovenia (1941-1946). International Law Study), which was published in 2005. Similarly, Vladimir Geiger in his book Josip Broz Tito $i$ ratni zločini. Bleiburg - Folksdojčeri (Josip Broz Tito and War Crimes. Bleiburg Volksdeutsche), published in 2013, analyzes the legal responsibility for committed crimes. Yale professor Mirjan Damaška, a well-known scholar of comparative and international law, offers compelling arguments regarding Tito's legal accountability for Bleiburg in his 2009 book Tito: Tajne vladara. Najnoviji prilozi za biografiju 
Josipa Broza (Tito. Secrets of a Ruler: Latest Contributions for the Biography of Josip Broz).

Regardless of all these publications, Croatian society is still greatly burdened with numerous discussions about the responsibility for the committed crimes. This discussion is deeply influenced by politics and its daily interests. Moreover, many citizens of Croatia still share a black or white perspective of the whole topic, where one side is considered guilty, while the other is completely innocent. Thereby, it is forgotten that no one, not even the winners in a bloody conflict such as the Second World War, could have (nor has) the "right" to a clean conscience (Esbenshade, 1995: 79).

Another brief analysis of the post-war events can be found in Slavko Goldstein's book 1941. Godina koja se vraća (1941: The Year that Keeps Returning), published in 2007. By the same token, great expectations were related to Josip Jurčević's book Bleiburg. Jugoslavenski poratni zločini nad Hrvatima (Bleiburg: Yugoslav Post-war Crimes against Croats), published in 2005. This book does not elaborate the Bleiburg problem as its primary focus. It offers only a superficial overview of the events that occurred in May 1945, corresponding to a persisting, but not sufficiently documented interpretation of the author. A similar political agenda can be found in another book by Jurčević, entitled Prikrivena stratišta i grobišta jugoslavenskih komunističkih zločina (Hidden Killing Sites and Graveyards of Yugoslav Communist Crimes), published in 2012. Unfortunately, this monograph is in fact a compilation (with minor additions) of research results conducted by the Commission of the Government of the Republic of Slovenia for resolving the question of hidden graves, the Commission for resolving the question of war and post-war victims in Croatia, and the State Commission for secret graves of those killed after 12 September 1944 in Serbia, with little additional interpretation or analysis.

It is not unusual to find interpretations that always emphasize solely the suffering of Croats, and in much of the existing literature the authors suggest that the crimes committed at Bleiburg and on the Death Marches had an exclusively antiCroat connotations. However, the more scholarly historiography has proven this kind of interpretation to be completely wrong and unjustified.

Approaching the issue from the left-wing perspective, the Alliance of Antifascist Fighters and Antifascists of Croatia published a book of proceedings entitled Bleiburg i Križni put 1945. (Bleiburg and the Death Marches 1945, 2007), which brings together papers presented at a symposium held in 2006 in Zagreb. Although the chief editor, Juraj Hrženjak, noted that the proceedings were based on an "objective truth", the publication of this book did not contribute any significant new details about the post-war events. In fact, its results were quite the opposite. Only few of the published articles make a shift regarding the perspective and methodo- 
logy, while the vast majority of articles are composed "according to the expectations and requirements" (Strčić, 2007; Ivin, 2007; Fumić, 2007). If scholars condemn only certain crimes under the cover of an "objective truth" (in this case the crimes committed during the Ustaša regime), and justify other violations of human rights because of the positive achievements of the anti-fascist movement, Croatian society and the field of history will be trapped in an endless cycle of ideologically determined interpretations of the past.

On the other hand, I attempt an overall analysis of the available archival sources and the published literature in Bleiburg i križni put 1945. Historiografija, publicistika i memoarska literatura (Bleiburg and Death Marches 1945. Historiography, Journalism and Memoirs), published in 2009 and reprinted with additional material in 2015. Similarly, there is also a useful review of important literature that was compiled by Vladimir Geiger in his article "Osvrt na važniju literaturu o Blajburgu 1945" ("Review of important literature about Bleiburg 1945"), published in the journal Istorija 20. veka in 2003.

According to all of the above-mentioned studies on Bleiburg, it is possible to conclude that in the past twenty-seven years many studies have been published in Croatia that deal with the still controversial events from May 1945. Altogether, their content differs, but most titles are memoirs or commemorative books. Therefore, for a large part of them one can say that they did not contribute any new analytical, theoretical, or documentary revelations, and their authors remain entrenched in the previously held interpretations and biases. However, some exceptions listed here are a good indicator of how things are slowly moving in a positive direction.

The publication of archival documents is of key importance to this topic. Moreover, researchers can use numerous published and publicly available testimonies, which the historiography treats as secondary sources. However, this kind of documentary material can provide useful insights and context, as well as giving additional information about events noted in the primary sources. Only thorough historiographical research, accompanied by an interdisciplinary approach and cooperation between different institutions, might resolve the numerous debates that are still vivid and mostly related to questions about the number of victims at Bleiburg and on the Death Marches, the legal qualifications of the crimes, and the responsibility for the committed acts. However, it seems that Croatian society still is not fully willing to accept different interpretations of these events or some of the more recent historiographical concepts (commonly referred to as the revision of history). Only when these conditions are accomplished, Bleiburg and the Death Marches will become what indeed they should be - a part of history. 


\section{REFERENCES}

Basta, Milan. 1980. Rat je završen 7 dana kasnije. Globus. Zagreb.

Bekić, Darko. 1989. Slučaj Bleiburg: nova istraživanja, nova iskušenja. Časopis za suvremenu povijest, (21), 1-3: 197-214.

Bilandžić, Dušan. 1999. Hrvatska moderna povijest. Golden marketing. Zagreb.

Cowgill, Anthony, lord Brimelow, Thomas and Booker, Christopher. 1990. The Repatriations from Austria in 1945. Cowgill Inquiry. The documentary evidence reproduced in full from British, American, German and Yugoslav sources. Sinclair-Stevenson. London.

Crljen, Danijel. 1966. Bleiburg. Hrvatska revija, (2-4), XVI: 263-297.

Čalić, Marie-Janine. 2013. Historija Jugoslavije u 20. veku. Clio. Beograd.

Esbenshade, Richard S. 1995. Remembering to Forget: Memory, History, National Identity in Postwar East-Central Europe. Representations, Special Issue: Identifying Histories: Eastern Europe Before and After 1989, vol. 49: 79.

Fumić, Ivan. 2007. Uzroci i posljedice Bleiburga 1945. godine, in: Hrženjak, J. (ed.): Bleiburg i Križni put 1945. Savez antifašističkih boraca i antifašista Republike Hrvatske. Zagreb: 59-68.

Goldstein, Ivo. 2003. Hrvatska povijest. Novi Liber. Zagreb.

Goldstein, Ivo. 2008. Hrvatska 1918. - 2008. Novi Liber, Europapress holding. Zagreb.

Goldstein, Ivo. 2011. Povijest Hrvatske 1945. - 2011. 1. svezak. Europapress media. Split.

Goldstein, Slavko and Goldstein, Ivo. 2011. Jasenovac i Bleiburg nisu isto. Novi Liber. Zagreb.

Ivin, Danijel. 2007. Smisao Bleiburga, in: Hrženjak, J. (ed.): Bleiburg i Križni put 1945. Savez antifašističkih boraca i antifašista Republike Hrvatske. Zagreb: 42-46.

Jareb, Jere and Omrčanin, Ivo. 1977-1978. The end of the Croatian Army at Bleiburg, Austria in May 1945 according to English Military Documents. Journal of Croatian Studies. XVIII-XIX: 115-182.

Steindorff, Ludwig. 2006. Povijest Hrvatske od srednjeg vijeka do danas. Naklada Jesenski i Turk, Institut društvenih znanosti Ivo Pilar. Zagreb.

Strčić, Petar. 2007. Čemu danas nedoumice oko Bleiburga i Križnoga puta, in: Hrženjak, J. (ed.): Bleiburg i Križni put 1945. Savez antifašističkih boraca i antifašista Republike Hrvatske. Zagreb: 9-30.

Martina Grahek Ravančić is Research Associate at the Croatian Institute of History.

Mailing Addresss: Martina Grahek Ravančić, Croatian Institute of History, Opatička 10, 10000 Zagreb.E-mail: martina@isp.hr 